\title{
Fire normativities: environmental conservation and quilombola forms of life in the Brazilian savanna
}

\author{
Guilherme Moura Fagundes ' \\ ' Universidade de Brasília, DF, Brasil
}

\begin{abstract}
The article seeks to shift away from the centrality attributed to the idea of 'control' in the debate on participatory fire management. To do so, it addresses three modes of existence of the phenomenon in the Brazilian savannah - queimada (burned place), fogos gerais (fire that spreads or general fires) and fogo fora do tempo (fire out of time) - aiming to explore the perceptual disparities between wanted and unwanted fires with quilombolas and environmental managers in the Jalapão region (Tocantins, Brazil). This problem is discussed in light of the concept of normativity formulated by the epistemologist George Canguilhem in dialogue with the anthropology of techniques. The goal is to contribute to a research agenda in which the distinction between 'good fire' and 'bad fire' is thematized in specific ethnographic contexts rather than from pre-given normative criteria. I conclude by arguing that the current fire management policies concern not only the legal protocol of fire authorization, but also the modulation of technical and vital processes.
\end{abstract}

Keywords: Fire management; techniques; vital normativities; quilombolas; natural parks; cerrado. 


\section{Normatividades do fogo: conservação ambiental e formas de vida quilombola na savana brasileira}

\section{Resumo}

O artigo busca deslocar a centralidade dispensada à ideia de "controle" no debate sobre manejos participativos do fogo. Para isso, aborda três modos de existência do fenômeno na savana brasileira - queimada, fogo que abre e fogo fora de tempo -, visando explorar as disparidades perceptivas entre os fogos desejados e indesejados junto a quilombolas e gestores ambientais na região do Jalapão (TO). Este problema é discutido à luz do conceito de normatividade, formulado pelo epistemólogo George Canguilhem e em diálogo com a antropologia das técnicas. O objetivo é contribuir para uma agenda de pesquisa na qual a distinção entre "fogo bom" e "fogo ruim" seja tematizada em contextos etnográficos específicos e não a partir de critérios normativos dados de antemão. Finalizo argumentando que as atuais políticas de manejo do fogo não incidem apenas no registro jurídico de autorização de queima, mas sobretudo na modulação de processos técnicos e processos vitais.

Palavras-chave: manejo do fogo; técnicas; normatividades vitais; quilombolas; unidades de conservação; cerrado. 


\title{
Fire normativities:
}

\section{environmental conservation and quilombola forms of life in the Brazilian savanna}

\author{
Guilherme Moura Fagundes
}

\section{Introduction'}

"You find it so and yet do not. Everything is and yet is not..."

Riobaldo, Grande Sertão: Veredas

In the anthropology of techniques, it has already become a classic approach to treat fire as an elementary means of action over matter. In this literature, the phenomenon is depicted alongside the actions of grasping and striking, extending and completing the effects of the human hand in the techniques of fabrication, acquisition and consumption (Mauss 2007 [1947], Leroi-Gourhan 1984, Sigaut 1975). More recently, ethnographies have foregrounded the technical status of fire in association with environmental management, whether linked to the management of protected areas, or as a tactic to combat wildfires (Ribet 2009, Dumez 2010). Its technicity, however, elicits ambivalences: when 'controlled,' it is a tool useful for clearing swiddens, hunting and making craftwork; when not, it is a hostile force, responsible for wildfires.

As Nadine Ribet (2018) astutely argues, inspired by Gaston Bachelard's psychoanalysis of fire (1964), the ambivalence of fire does not reside in the combustion itself, but in the effect of the affections through which we relate to the phenomenon. It is the affects animating these relations that are responsible for conferring good or bad values to the flames, meaning that fire functions rather as a support for ambivalences exterior to it (Ribet 2018: xiii). Not by chance, this projection of ambivalence onto the phenomenon has been historically stabilized through decrees, codes and legislation in which fire's technical status is stipulated in legal-normative arguments. Consequently, the criteria for distinguishing between 'good fire' or 'bad fire,' between tool and contravention, are selected in a decontextualized - or more precisely, as I intend to argue in this text, a de-environmentalized - way.

The fact is that the legal framing of this distinction exploits arguments exterior to the interactions that fire promotes in the environment, and is, therefore, not supported by its modes of existence in singular configurations. Instead it is founded on a typology that is ultimately tautological, appealing to predicates like 'rational,' 'planned' and, most commonly, 'controlled.' In the Brazilian case, Garda and Berlinck (2016) observe that Decree 97.635, issued in 1979, responsible for the regulation of the 1965 Forest Code and that until very recently guided the use of fire in Brazil, was the first national legal text to propose a definition of the category incêndios, or wildfires. As well as being the first to prescribe the use of 'controlled fires,' the decree also instituted the 'National System for Preventing and Fighting Forest Fires,' also known as Prevfogo, which gave rise to the organizational apparatus of the wildfire brigades in Brazil. Article 1 of the decree defines an incêndio, wildfire, as "an uncontrolled fire in any form of vegetation." In this definition, the predicative 'control'

\footnotetext{
1 This text is the result of the welcome and sharing of knowledge of the quilombola Deni and his family in the town of Mateiros (Tocantins, Brazil). I also thank Perig Pitrou for the opportunity to present an early version of the text in the seminar "Anthropologie de la vie et des représentations du vivant," in June 2017 at EHESS. At the time I was engaged in a period of doctoral research, financed by CAPES, at the Laboratoire d'Anthropologie Sociale (LAS, Paris). The text also counted on the generous observations of Ana Carolina Barradas and two anonymous reviewers to whom I extend my thanks.
} 
is mobilized without any mention of the diverse forms of expression that fire can assume in correspondence with the phytophysiognomic quality of the vegetation, the season of the year and the associated forms of life.

This typological differentiation between controlled burn and wildfire, founded on the aspect of 'control,' is also present in the 'Firefighter Training Manual for Preventing and Fighting Forest Fires,' where controlled burns and wildfire are respectively defined as (i) "an agricultural or forestry practice in which fire is used rationally, that is, controlling its intensity and confining it to a predetermined area, acting as a production factor," and (ii) "any uncontrolled fire that impacts on any form of vegetation, whether provoked by human action (intentional and negligence) or by natural cause (lightning)."

Any attempt to normalize vital processes undoubtedly requires a system of objective measures to delineate their calculative management (Foucault 2010, Rabinow 1999). Even so, in terms of the normalization of the difference between a controlled burn and wildfire, there are important points of mediation. After all, how can the experience of 'control' be measured? Here formulations of a purely quantitative kind, based on measuring the physical behaviour of the fire, yield to perceptual engagements that qualitatively depend on perceiving subjects. Pyne $(1984,2012)$, for example, typically argues that the differentiation between controlled burns and wildfire is not related to the physical properties of fire but rather to the 'cultural contexts' in which the phenomenon occurs. This is because the differentiation concerned, based on the presence or absence of 'control,' is not situated in the ontological dimension of combustion per se, but in the relations established with fire. While the intensity of fire can be measured through "Byram's equation," ${ }^{2}$ the valorative ambivalence of its diverse modes of existence can only be apprehended when contextualized in concrete environments. It is here that the primacy of objectivism makes its own limits explicit, demanding a more relational and inclusive view of expressions of fire in specific contexts.

In this article I invest in an interdisciplinary dialogue between anthropology and the biological philosophy of techniques with the aim of providing an alternative methodological path to the reframing of this problem. To this end, I set out from an ethnography developed in Jalapão over eleven months of research, between 2014 and 2016, with the quilombola geralistas, ${ }^{3}$ firefighters and environmental managers of the Serra Geral do Tocantins Ecological Station (hereafter EESGT). In a context shaped by the territorial overlap between the natural park and the quilombola territory, I seek to demonstrate how the articulation between anthropology and the biological philosophy of techniques enables us to comprehend the divergences between desired and undesired fires in a more relational manner true to its modes of existence in the gerais environment.

\section{Overlaps in the gerais}

The gerais is the name given to an extensive savannah area located in central Brazil, composed of areas of denser vegetation (chapadas), open areas (campinas), forests (capões) and wetlands (vargens, veredas and varjões) where water is perennial and abundant even in the dry season. The imagery irrevocably associated with this 'place of the sertão' revolves around the signs of freedom, isolation and immensity, so well depicted by João Guimarães Rosa in his monumental novel Grande Sertão: Veredas (2001). As the socioanthropological literature has highlighted (Andriolli 2011, Ribeiro 2010, Jacinto 1998, Lindoso 2014, Sobrinho 2012, Nogueira 2009), these predicates are pertinent to a description of both the people inhabiting the region and also to the cattle breeding system na solta (loose, without fences).

\footnotetext{
2 Byram (1959) defines the variable intensity as "the rate of energy or heat released per unit of time and length of the fire front." In formal terms, Byram's equation ( $\mathrm{I}=\mathrm{Hwr}$ ) conceives fire intensity (I) as the result of the fuel available (w), multiplied by the heat yield (H) and the speed of fire spread (r).

3 Quilombola refers to the people living in quilombos, settlements historically founded by African slaves who escaped from plantations and others oppressive relations (see Arruti 2006). I use the native expression geralista to designate the population whose way of life is developed in the environment called the gerais. It should be stressed, however, that this category is used in an everyday fashion in Jalapão, without the strong sense of identification associated with the category quilombola or with geraizeiros, as described by Nogueira (2009) in the northern region of Minas Gerais state.
} 
Concerning the gerais of Jalapão, located between the eastern portion of Tocantins state, the west of Bahia and the south of Piauí and Maranhão, an abundant literature exists surrounding 'expeditions' to the region, in which some mention of the queimadas is common. ${ }^{4}$ These accounts range from those of foreign naturalists to engineers employed by the Old Republic (Miranda 1936) and, more recently, geographic (Paternostro 1934, Pereira 2014 [1942], Geiger 1942) and conservationist expeditions (Von Behr 2004, Faleiro 2002). Historically, the gerais of Jalapão is the place of refrigério ${ }^{5}$ of herds bred under the solta system, where the cattle wander over large distances in search of pastures renewed by fire. Until the mid-eighteenth century it formed a corridor for indigenous people from the Xerente and Acroá groups (Santo 2013, Apolinário 2005). But from the end of the nineteenth century the gerais of Jalapão became inhabited by black cowherds coming from the south of Piauí and the semi-arid region of Bahia who at the time tended, or more precisely, campeavam (grazed) the cattle of large ranchers in the verão (summer). There are also local accounts of families coming from the semi-arid and western regions of Bahia who came to Jalapão for various reasons, fleeing from slavery, extreme droughts and raids by the revoltosos (rebels) of the Prestes Column. ${ }^{6}$ All these migratory vectors helped establish the family groups that today form the quilombola communities in Jalapão. ${ }^{7}$

Overlapping the gerais of Jalapão, seven Conservation Units (CU) have been created since 2000, including the EESGT. The latter is a full protection CU located in an area of 716,000 hectares in the southern part of Jalapão. Created in September 2001, initially under the management of the Brazilian Institute for the Environment and Renewable Natural Resources (IBAMA), and since 2008 run by the Chico Mendes Institute for Environmental Conservation (ICMBio), the EESGT is one of the country's most inflammable protected areas, responsible for some $35 \%$ of the area burnt annually in federal CUs (Barradas 2017). The northern portion of the EESGT overlaps with the quilombola territory claimed by the Association of Quilombola Communities of Rio Preto, Rio Novo and Riachão (Ascolombolas-Rios). The latter comprise twenty-one domestic groups that, though inhabiting the area within the $\mathrm{CU}$ more of the year round in the past, were forced to cease using these areas following the arrival of environmental agencies in the region. Today, in parallel with the movement to recover their territory, they mostly reside in the town of Mateiros (TO) and utilize the quilombola territory periodically for diverse activities, including to campear (graze) cattle, hunt, tend plantations and harvest golden grass, capim-dourado (Syngonanthus nitens), a species endemic to the region. ${ }^{8}$

This was the first full protection CU to expressly permit the use of fire by quilombola communities with territories overlapping the conservation areas. In the last seven years a series of regional articulations have been undertaken by the managers of the EESGT and other CUs with the intention of agreeing legal certainty mechanisms that guarantee the conservation of biodiversity in association with the rights of the quilombola families who inhabit or utilize the areas within these protected reserves. Among these actions, in 2012 ICMBio and Ascolombolas-Rios signed a 'Term of Agreement' (TA) stipulating rules for coexistence between the EESGT and the communities linked to the northern region of the CU. Although the TA is not limited to regulatory fire

\footnotetext{
4 Hereafter I shall use queimada in italics when I am referring to the spatiotemporal sense of burned place as assumed by the category for the geralistas.

5 The category refrigério encompasses all of the gerais of Jalapão (including the landscapes of veredas, campinas, chapadas and carrascos) and refers to a very specific type of spatiotemporal relationship with the environment. It is a transhumant zone to which cattle are brought at the beginning of the dry season (or verão, summer) in search of year-round water and wild grass whose post-fire shoots provide fodder for cattle during the dry spell. The cattle are led back to the roças de pasto (pasture fields) after the first rains.

6 The Prestes Column was a controversial political movement (Brum 1994) under the command of the communist military office Luís Carlos Prestes, which rebelled against the Old Republic between 1925 and 1927. Not only because they were insurgents, but also due to the group's aggressive behaviour, as well as the fear they provoked in the rural communities, they became known as revoltosos (rebels, also 'the enraged ones'). Although the Column passed through the west of Bahia and some of the settlements in the area around Jalapão, it does not seem to have entered the more remote areas.

7 Today there are five quilombola communities in the Jalapão region that have already been recognized by the Brazilian agency responsible for identity certification (Palmares Cultural Foundation), but they are still waiting for land regularization.

8 In terms of plant taxonomy, the species is included in the Eriocaulaceae family, one of the flowering plants among the popular evergreens used to make craftwork and biojewellery. For the Jalapoeiros, however, this coveted plant is seen as a grass. This definition tells us much about its close interaction with cattle herding practices, since burning the vargens (savannah) stimulates both the regeneration of golden grass and new shoots of the wild grass used to feed the cattle.
} 
use in this situation of territorial overlap, in the TA review workshops the preponderance of burn practices is demonstrated above all by its constant intersection with other topics.

Figure 1 - Localization of the EESGT with its state and municipal boundaries.
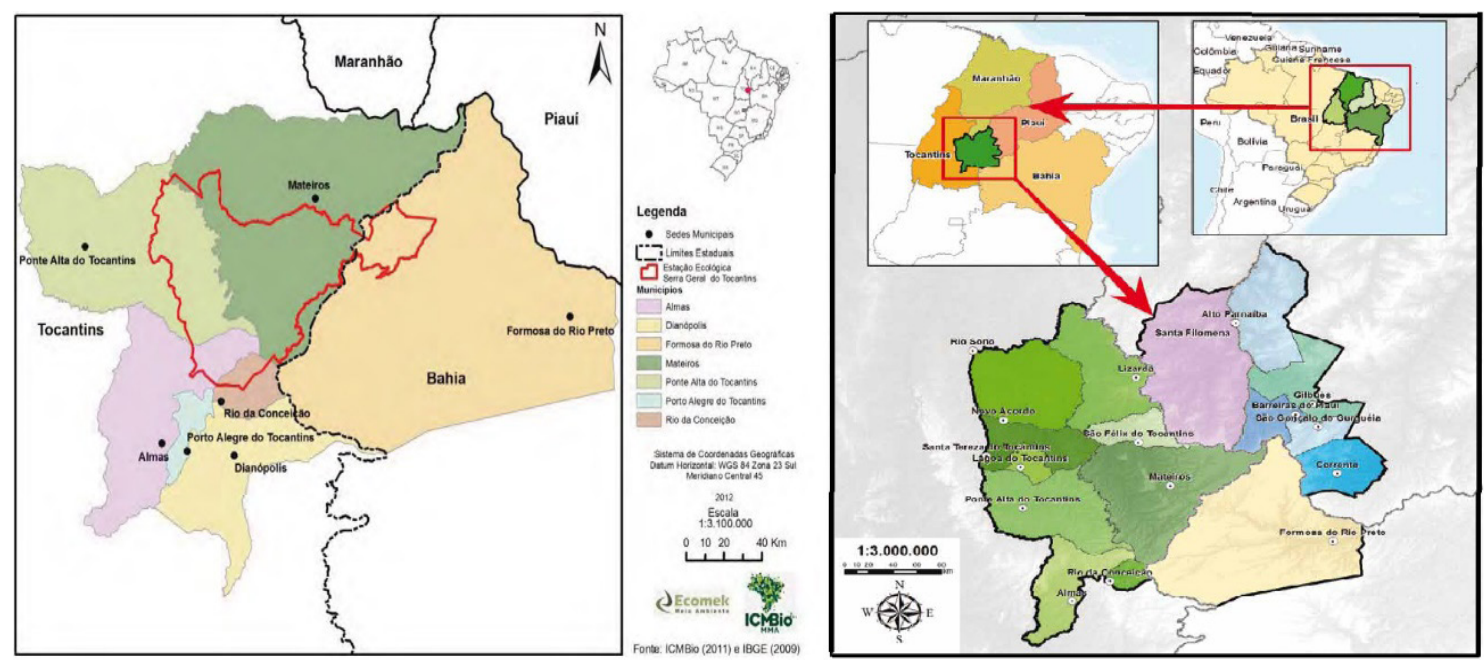

Source: adapted from Barradas et al (2014).

Figure 2 - Territorial overlaps within the EESGT. The yellow line demarcates the territorial boundary of the CU, while the green line delimits the 'use areas' of the families signatory to the Term of Agreement. The blue dots indicate the location of the current houses and the red dots the houses that are no longer inhabited. The red patch indicates the quilombola territory of the Ascolombolas-Rios association, in accordance with the coordinates provided by the Brazilian agency responsible for quilombola certification (Palmares Cultural Foundation). Lastly the continuous dots in blue, to the right of the map, show the location of the another community, called Comunidade dos Prazeres.

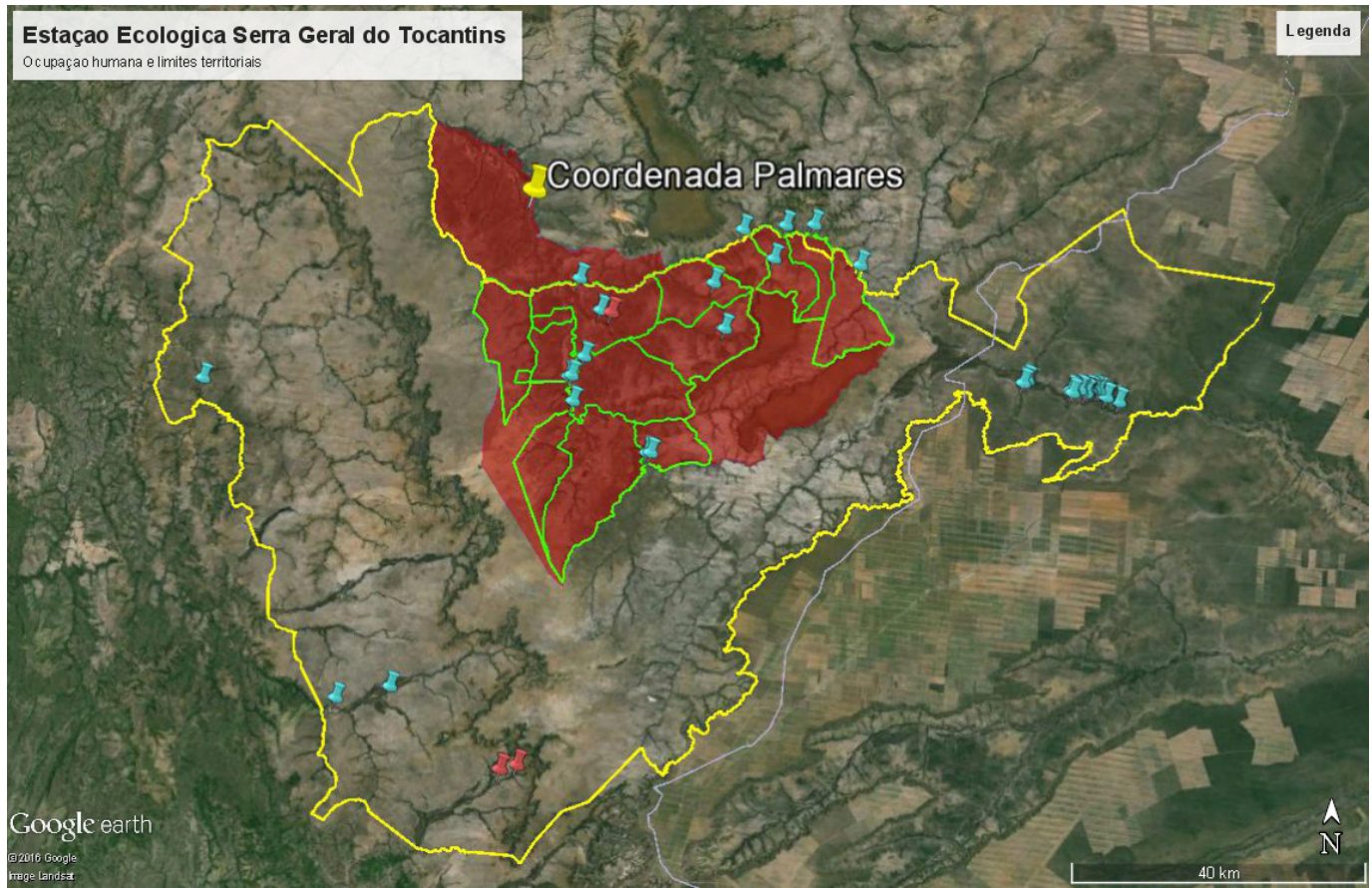

Source: adapted from the files of the EESGT. 


\section{Good fire, bad fire}

We're developing a methodology to define the kind of fire we don't want, what good fire is and what bad fire is. The size of the area is not enough alone to say whether a fire is a wildfire [incêndio]. It also matters where it occurred, because it's different when it's in a forest. How long this fire spent burning... The time of year when it burnt... Whether it was August, September... We would look at a series of factors in order to say whether it was a wildfire. We need to reach a consensus to understand what we mean by a wildfire. We don't have a completely scientific concept, but we are in agreement here that we don't want a fire with such-and-such characteristics. (Máximo Menezes, environmental analyst for EESGT)

The citation above is taken from a meeting involving environmental managers from the EESGT and quilombola geralistas. It was November 2015 and the meeting was the fourth workshop held to develop a new version of the TA. Before entering into detail concerning the various different types of fire, however, in an attempt to encompass quilombola rights and conservations duties, a significant proportion of the workshop had to be spent on 'conceptual definitions.' Among them, especially, the attempt to reach a consensus on what would be a controlled burn, taken as a 'good fire,' and a wildfire, taken as a 'bad fire.' Without this common understanding, no regulation could be created and pactuada, agreed or 'pacted,' as local people say.

The TA review process was being developed in Jalapão during the emergence of the proposal for 'Integrated Fire Management (IFM). In 2012 work was begun on the project 'Prevention, Control and Monitoring of irregular burns and forest fires in the Cerrado' (also known as the 'Cerrado-Jalapão' project), seeking to improve prevention of wildfires and control of burns through the implementation of the IFM approach throughout the region. The project aims to conserve the biodiversity of the cerrado and contribute to maintaining this biome as a carbon sink of global importance. It forms part of a global movement towards rehabilitating the use of fire as an 'environmental management tool' where Brazil is just one of the many countries involved.

In natural parks in the Australian savannah (Russell-Smith et al. 2013), the African southwest (Trollope 2011) and Latin America (Bilbao et al. 2010), to pick just a few cases, the paradigm of suppressing fire and fighting forest fires has undergone major transformations over the last half century. This change in perspective concerning fire emerges along with a scenario that combines not only the frustrated attempts of environmental managers to supress increasingly sever and frequent wildfires, but also transformations in the scientific paradigms themselves. For sure, the ecological debates surrounding the concept of 'pyrodiversity,' which seeks to analyse various effects of the diversity of fire regimes, are still heated and controversial (Martin and Sapsis 1992, Parr and Andersen 2006, Bowman et al. 2016). However, it is increasingly certain that the 'zero fire' paradigm, hegemonic until the start of the twenty-first century, has demonstrated its failure in the face of the increasing recurrence of large forest fires. A symptom of this change in attitude is the proliferation of singular styles of wildfire prevention and combat, already including its own ethnographic literature (Ribet 2009; Dumez 2010; Fowler 2013).

In the Brazilian setting, the IFM is rapidly becoming consolidated as a public policy, its initial objective being to alter the seasonality of burns in the conservation units where this approach is being implemented. It comprises an experiment in relocating most of the areas burnt at the end of the dry season ('late' burn) to the beginning and middle of the burn calendar ('early' and 'modal' burn). To this end, the management initiatives are primarily concentrated on the burns planned for the start of the dry season, aiming to fragment the plant fuel and prevent the emergence of large and intense fires, typical of the end of the fire season.

These initiatives are undertaken in four stages. During planning, satellite images are transformed into maps that enable the quantity of plant fuel to be visualized and priority management zones to be subsequently chosen. During execution, the CUs are supported by pickup trucks, all-terrain vehicles, burning equipment (driptorches), offline digital map applications (Avenza Maps) and local residents (many of them quilombolas) 
hired to work as 'management agents' in implementing the burns. There are also the monitoring and evaluation phases during which research for the control and surveying of burnt areas through satellite images enable the scale and intensity of the fire to be measured and compared during the 'early,' 'modal' and 'late' periods.

As the name suggests, the IFM also aims to 'integrate' scientific, local and management knowledge and practices, looking to reconcile agropastoral and conservationist goals. In this respect, not only in Brazil but in other countries too, the approach is associated with the agendas of 'managing socioenvironmental conflicts,' involving traditional populations whose territories coincide with conservation units (Eloy et al. 2018; Barradas 2017; Mistry et al. 2016; Falleiro et al. 2016). An important synthesis of this articulation between scientific ecology, environmental management and community involvement was systemized in the report Living with Fire, edited by the US ecologist Ronald Myers (2006). This text is one of the major vectors in the diffusion of the IFM approach in Latin America, promoting a triangulation between the socioeconomic importance of fire for local communities, the monitoring of the burns based on studies in fire ecology, and strategies for suppression and prevention. No less important are the didactic resources that have been deployed to reconcile the pyrophobia of the institutions and the pyrophilia of the local communities. Among them, perhaps the most emblematic, is the slogan around which Ronald Myers bases his scientific primer, "the two faces of fire: good fire versus bad fire" (Myers 2006: 16), differentiating them as controlled burn and wildfires through the criterion of the presence or absence of 'control.'

Although this rhetorical differentiation has contributed both to the legal relaxation in the use of fire in environmental management activities and to the 'education' of traditional populations in avoidance of 'bad fire,' it is insufficient in itself to provide consistent criteria for reaching agreement in disputes involving very disparate perceptions and engagements with fire, such as the encounter between quilombolas and environmental managers. Indeed, even within environmental management, the perception of what constitutes a wildfire has transformed significantly following the advent of the IFM. Managers often state that prior to this new approach a fire that burnt for more than 24 hours would already be considered a wildfire, forcing them to mobilize the entire firefighting apparatus. A purely spatial aspect would also once have been an indicator of an 'out of control' blaze: in the case of the EESGT, up until 2014, a fire that burnt across an area equivalent to 80 hectares was already considered a wildfire.

The fact is that with more sophisticated processing of satellite imagery, the research in fire ecology that has accompanied the new policy, and, above all, the reapproximation of fire managers to issues beyond firefighting without mentioning the importance of the experience shared by local residents hired as management agents - it has become much more difficult to maintain any standard definition of wildfire. Nevertheless, the centralization of the national fire management bureaucracy demands 'data' and reports that provide comparative proof of the effectiveness of the new policy. Due to the need to compare with other CUs, the notion of wildfire (incêndio) has become ever more closely linked to the division of the burn calendar into three periods: 'early' (May and June), 'modal' (July and August) and 'late' (September and October) - with wildfire defined as those fires that fail to extinguish at night during the 'late' period, the height of the dry season.

The relationship between environmental management and quilombolas concerning the pactuação (pact, agreement) on desired and undesired fires has also altered substantially. Before the arrival of the environmental agencies in Jalapão, there was no expression used by the quilombolas that encompassed all types of undesired fires. While today the word incêndio competes for this place along with an antagonistic perception of 'good fire' and 'bad fire,' it also forms part of a wider range of possibilities. Here I refer to expressions like: fogo vaporado (steamed fire), fogo desonesto (dishonest fire), fogo violento (violent fire), fogo que vai até Ponte Alta (fire that spreads as far as Ponte Alta town), fogo de cru de 3 anos (three-year old raw grass: dry wild grass), fogos gerais (general fires), fogo embalado (rapid fire) and fogo variado (unpredictable fire), used to designate fires whose origin, temporality or scale are, in some form, contrary to what the quilombolas perceive as a queima sadia 
(healthy burn). On the side of the managers, meanwhile, rather than fire being treated as a management tool, any burn made by the quilombolas affecting more than 80 hectares was already seen to exceed the 'ceiling' of a burn and would be treated, therefore, as a wildfire. ${ }^{9}$ This threshold started to become obsolete from the moment when the managed burns implemented by the environmental management itself began to spread across around 3,ooo hectares in a single burn expedition. However, although managers no longer act by only indiscriminately reducing the extent of the burn, the calculations of area and time continue to be important reference points for them to decide what constitutes a wildfire and then work to reduce it.

As I shall attempt to demonstrate through the ethnography, the disparity between burning excessively and burning in a healthy way (queima sadia) should not be reduced to a merely conceptual misunderstanding or disagreement. It is clear that, in pragmatic terms, geralistas and environmental managers agree on the dangers of wildfires, which become predicated as 'bad fires,' made at the height of the dry season, especially between the months of August and September, in an uncontained area. However, the perception of the geralistas concerning fires conceived as undesired goes beyond any framing in temporal (early/late) or spatial (much/ little) terms. The fact is that there are undesired fires even in situations taken to be safe by environmental management. But the difficulty here is of another kind, less compatible with the quantitative variations in a fire's scale and intensity, and, as I aim to show, more compatible with the rhythmic (spatiotemporal) qualities of fire in relation to the forms of life (Pitrou 2017) associated with it. ${ }^{10}$

It is clear that with the new opening to dialogue and coexistence enabled by the IFM, even environmental managers have begun to perceive the dynamics of fire in the gerais in more complex fashion. But the disparity is still maintained, especially due to the reports, operational plans and proofs of efficiency that managers find themselves compelled to produce. Their problem consists of translating a universe of relations in which undesired fires are more dynamic than a normativity understood merely as quantitative variation, whether spatial or temporal. Before entering into the specificities of this geralista universe, it is worth briefly discussing how the articulation between anthropology and the biological philosophy of techniques can provide us not only with theoretical insights, but above all a methodological apparatus capable of responding to the problem of normativities.

\section{Beyond 'control': the anthropology of techniques and vital normativities}

One of the biggest contributions made by the anthropology of techniques is found perhaps not just at the theoretical level - that is, in the way in which technique ceases to be conceived in utilitarian terms - but above all in what we could call a methodological turn. In his manual of ethnography, Marcel Mauss alerts us to the fact that "absolute precision is indispensable in the observation of techniques" (Mauss 2007: 24, original emphasis). This 'precision' evoked by Mauss is accompanied by a centrifugal force in his anthropological style: in order to match the biopsychosocial totality of technical phenomena, the ethnographer should always inhabit the "frontier of the sciences" (Mauss, 2003: 401), sometimes mobilizing methodological resources alien to conventional humanist training.

Two of Mauss's leading disciples transited freely, though not without considerable rigour, through disciplinary areas closely affiliated to anthropology. An ethnologist and student of Mauss, André-Georges Haudricourt (1911-1996) was also an agronomist and linguist, possessing a training that provided him with

9 Ana Carolina Barradas, environmental analyst for EEGST, personal communication.

10 I use the concept of 'form of life' taking Pitrou (2017) as my main reference, particularly where the anthropologist articulates both ethnobiological reflections on the diverse biological life forms and the anthropological and philosophical propositions concerning human conventions, engagements and forms of life. Without any pretence of exhausting its theoretical profusion in the history of philosophy, the concept of forms of life serves me here as an analytic operator to explore the inseparability between the life forms of the gerais (cattle herded na solta, golden grass, rheas, deer and so on) and the way of life of the quilombola geralistas. 
the grounding in the internal characteristics of animal behaviour and plant physiology necessary for him to advance in innovative intuitions concerning domestication processes (Haudricourt 1962, Ferret 2014). The case of André Leroi-Gourhan (1911-1986) was no different: also an ethnologist and heir to the Maussian tradition, but closer to the field of prehistory and palaeontology. It was especially through the use of research procedures taken from archaeology that Leroi-Gourhan was able to arrive at a detailed analysis of technical gestures, emphasizing motricity and rhythms as prior to the human and responsible for instituting the social (LeroiGourhan 1993, Bidet 2007). Inspired by Mauss's anthropological style, Haudricourt and Léroi-Gourhan bring us closer, paradoxically, not to a culturalism limited to the symbolic dimensions of actions but to a biological perspective of techniques. Such an affirmation does not imply reducing the human to 'nature,' however but rather highlighting the strong interweaving of the social and the vital, the genesis of both informed by the rhythms that pervade humans and their environments.

The core of this epistemological project resides in exploring technical phenomenon in a pre-eminently concrete fashion, avoiding pre-given modern abstractions such as nature and culture, subject and object, action and words (Barbe and Bert 2009). This relational perspective true to the concrete was of great importance to the biological philosophy of techniques developed by Georges Canguilhem. A direct heir to the anthropology of Mauss and Léroi-Gourhan, ${ }^{11}$ Canguilhem dedicated the most influential strand of his research to the systematic study of medical doctrines based on their techniques - or more precisely, comprehending medicine itself as a technique. He does this by examining techniques in terms of the relations between organisms and their milieus, by contrast with the 'adaptationist' orientation that marks analyses centred on the relation between organism and environment.

The notion of 'milieu' is a central analytic operator for the anthropology of techniques, especially in its French current, but also has significant resonances in the British school. More recently, both Tim Ingold (2011: 70) and Gisli Palsson (2013: 26) have resorted to this notion as a means to implode an atomistic conception of organism ${ }^{12}$. A 'milieu' in this vitalist acceptation differs from an 'environment' as a physical fact since the former is instituted and singularized in the very relation established with the organism, while the environment is a context given apriori, indifferent to the relations established with it. In this sense, Canguilhem writes, "the organism is not thrown into an environment to which he must submit, but he structures his environment at the same time that he develops his capacities as an organism" (Canguilhem 1991: 284).

Canguilhem sets out from this notion of milieu in order to rethink the ontological dynamic of life (including technique) in terms of normativity (normativité) or a normative activity, a concept that had a pronounced impact on later French thought on technique (Simondon 2005a and 2005b, Guchet 2010). By normativity, contrasted with 'normalization,' Canguilhem means the creative potency possessed by a healthy organism that enables it to give origin to new forms of life. While normalization draws on an exteriority in relation to life in order to institutionalize, control, exert coercion, resolve conflicts and regulate the haphazard, the notion of normativity translates a kind of creative resistance immanent to life itself. It is through normativity or normative activity that an environment is transformed into a milieu vis-à-vis a determined organism. Or more exactly, it is through the very act of instituting its normative potency, imposing its vital values, that an organism assumes an environment as its umwelt or 'own world' (Canguilhem 2008, Uexküll 1982).

\footnotetext{
11 In his presentation to the text "La philosophie de la science de Georges Canguilhem: Epistémologie et Histoire des Sciences," by Pierre Macherey, later included in the afterword to the Portuguese edition of the book The Normal and the Pathological, Louis Althusser recognizes the debt owed by Canguilhem to ethnology: "the new epistemologists appear like ethnologists who do 'fieldwork': they go to see science up close and refuse to discuss what they know nothing about, or what they only know second or third hand" (Canguilhem 2002: 273, free translation). Canguilhem himself also justified this interdisciplinary approximation: "it is ethnographers who are today closest to constituting a philosophy of technique, in which philosophers have lost interest, since they have been attentive, above all, to the philosophy of science" (Canguilhem 2008: 93).

12 After the final version of this text was approved by the editors, I had access to Adriana Petryna's (2018) excellent article on her current research about how scientists are conceptualizing uncertainties and the phenomenon of "runaway nature" concerning wildfires. Although she is dealing with issues not addressed in this text, she also evokes the concept of milieu, even though she expresses her suspicion of what she calls "Canguilhem vital optimism".
} 
So what relevance does Canguilhem's notion of normativity have for the problem of distinguishing between controlled burn and wildfires? From the outset, we could argue that for quilombolas and environmental management alike a constellation of metaphors posits fire as a structuring element of environmental health albeit based on very disparate conceptions of what 'health' and 'environment' might be. But we can go further, arguing that a new research program is opened up by the very way in which Canguilhem appropriates the anthropology of techniques' reframing of the relationship between organism and milieu - devolving to the clinical (and, why not, the ethnographic) field the problem of distinguishing between normal and pathological. In proposing this approximation, the intent is not to abolish the frontiers between these two existential modes of fire, which would amount to a kind of naive relativism, less still of falling back on the official discourses found in the manuals and legislation centred around control, which would entail resorting to pre-given external values.

Neither is the aim of this interdisciplinary approximation between anthropology and philosophy limited to a theoretical level, which would end up eclipsing the ethnographic investment, turning anthropology into an impoverished version of philosophical canons (Ingold 2017). Here Canguilhem's contribution is situated at a primarily methodological level. Rather than taking controlled burn and wildfires as normal and pathological fire, respectively, it is a question of postulating the clinical anteriority of the ethnographic field. This implies exploring the relations that fire enables between the forms of life in the gerais and its milieus, comprehending the vital dynamics in its concrete activities.

\section{What can a queimada do?}

With considerable expertise in the topic, the environmental historian and manager Stephen J. Pyne (2012), author of more than a dozen books on the history of fire management in the USA, Europe and Australia, has called for a radical change in the way in which we approach the occurrence of fire in forest environments. Unlike floods, typhoons and earthquakes, whose manifestations on the planet preceded the appearance of the first life forms, fires are biophysical phenomena that cannot occur without the oxygen, organic matter and heat that make up the biota (Pyne 2012: 15). According to Pyne, this also entails taking seriously the vitalist metaphors concerning fire management that abound in ethnographic materials, where fire is treated as a being that rises, lies down, grows, feeds and dies. In fact, although fire is not itself a living organism, it is a product of life and for this reason can only be properly comprehended when analysed in terms of its vital dynamics.

Such being the case, it is important for an ethnography to comprehend first of all what theory of life we are talking about when we approximate fire to living dynamics. It is precisely this path that Perig Pitrou (2014) maps out in seeking to establish the programmatic foundations for an anthropology of life. This aim in mind, the French anthropologist asserts, the first task for any investigation must comprise a systematic examination of local conceptions of growth, reproduction, degeneration, healing, adaptation, interaction with the environment, sexual differentiation and movement, so as to extract from them ethnographic theories apropos the causes behind these phenomena (Pitrou 2014: 161).

Applying these methodological suggestions to the ethnographic case discussed here, we can take the actions assigned to fire in the gerais as elements of a geralista theory of life. ${ }^{13}$ Thus, an ethnography devoted to examining fire manipulation techniques should also include the living processes from which fire emerges, seeking to understand the seasonal functioning of the gerais and the rhythmic or spatiotemporal dynamics of fire within this environment. This can begin with the life cycle in the gerais, which divides into two clearly demarcated periods: inverno (winter) and verão (summer). In inverno, abundant rain is expected, while in verão it

13 Here I concur with Pitrou's definition of the term 'theory,' namely: "the forms of objectification that attest to the existence of this knowledge, as well as its consistency and stability" (Pitrou 2016:9). 
is the grass shoots that regrow after the burning of a vargem (meadow) that enable di cumê (feed) to be provided to living beings. Not only in Jalapão, but perhaps throughout the large area of central Brazil known as the gerais, the term queimada is a geographic category distinct from the controlled burn or the act of burning itself, such as it usually appears in legislation and in the normative debate on the agricultural use of fire. Instead, the term refers to the paths along which the fire has passed, eliminating the cru (dry grass) and stimulating the regrowth of native vegetation. The geralistas recognize at least five types of fire evaluated as normal over the course of the year, namely: aceiros (firebreaks), fogo de porta (door fire), queimada (burned place), fogo de precisão (precision fire) and fogo de roça (plantation fire). Calling these fires 'normal' does not mean that they necessarily occur, but that they provide fertility to the geralista forms of life and that their occurrences multiply the capacities for relocation in response to modifications in the milieu, especially those brought about by an intense summer or a winter with scant rainfall.

What the fire cycle helps us understand is how the queimadas should not be interpreted as disturbances alien to the dynamic of the gerais, but as a constitutive part of their forms of life. We could also can a step further and affirm that the fire cycle only makes sense when conceived processually, supplying a kind of historicity to relations constructed during contingencies. After all, there is nothing more alien to the geralista universe than a life devoid of events that deprive them of any possibility of action, guided by images stabilized in time and space. This is because, as well as the variations linked to the rain and the dry season, other vectors of force exist that make it non-viable for life to be lived under the imperium of stable laws, rules and commitments. One such vector are the fires that spread in unexpected manner, called fogos gerais. We can take as an example a fire that spread up in the area of my main quilombola host, the elderly Deni.

\section{Anomalies and confluences}

It was September 2016. Irecema and Berlarmina - Deni's wife and sister, respectively - had left for the plantation located at Bocaina swamp at daybreak, around 6am. On the way, the women came across a couple who were fishing and close to them rose a small plume of white smoke, which had from a far had looked like a bonfire. Around 10am, Deni gave me a ride as far as the town and continued on towards the Quatis swamp to fetch them. When he arrived there, on the side of the swamp, the sun already hotter, there was a large fire "licking everything" from Quatis to another swamp called Bocaina. Initially, Deni thought that the fire might have been lit by Veinho, his area neighbour. But he "hunted for the tracks" of his compadre (partner) and found nothing. As it was already too late to attempt any kind of action to contain the fire, Deni could only return home, perplexed with the situation, where I was waiting for him. On arrival, Deni told me what he had seen:

It [the fire] jumped right there above the ponte da lata [a place]. The swamp is narrow and the cru [dry grass] was this high! From one side to the other. So it jumped there. Because higher up it was already burnt from the previous year. From this side too it was also burnt. Over here there was a small strip on the vereda that had not burnt. There was a little swamp there [...] It jumped via this swamp and descended towards the varjão [big meadows] of Bocaina. A torado [relentless] fire. (Deni)

The next few days saw considerable speculation over who had been the mão quente, the 'hot hand.' Another compadre, dropping by for a morning coffee at Deni's house, brought news about the incident. He mentioned rumours he had heard about who had lit the fire: other people had caught sight of the arsonist "dragging the binga [lighter]" in Dedo Cortado's swamp. This was the exact same man who Iracema and Berlamina had seen fishing that same day. According to the compadre, the man concerned had lit the fire just to "clear the 
cru [dry grass]" and make it easier to move around where he was fishing. As the day was very hot and the cru old, the fire got out of control. He himself had fought hard to put it out, especially to save some cashew trees, but without success.

I asked whether the arsonist was a (cattle) breeder and whether his motive for burning had been to regerminate the grass. Deni said no. It was precisely this fact that had most annoyed Deni and Veinho, the two geralistas responsible for the area: it had been a fire made "without precision." But Deni recognized that there were forces that had magnified the fire beyond the initial human gesture of lighting it ("anyone can drag the lighter!"). The year in question had been extremely dry with little rain in February and the area had various "pockets of old cru." For Deni this configuration explained why the fire had spread. Rather than insist on discovering who was guilty and hold them responsible, the concrete problem at that moment was to find alternatives so that the cattle would not be left without di cumê (feed) for the following year.

The fact was that the fire 'without precision' that spread up from Bocaina to Estiva left Deni desagasalhado, 'uncovered,' unable to harvest golden grass that year, since it had burnt the vargens (meadows) where he had planned to gather it. Moreover, this fire also presented Deni and Veinho, area neighbours, with a dilemma: how would they feed the cattle the following year? For the current year, the incident meant that Deni's cattle would graze alongside Veinho's in this "queimadona [large burnt area] made without precision." But as well as allowing Deni and Veinho's cattle to feast on the new shoots of the vargens over the summer, this unpremeditated fire promised an abundance of golden grass the next year. Here we encounter, then, an affordance (Gibson 1979: 141) of the queimadas, or burned places, which permits the reincorporation of errors and chance: the relationship between cattle and golden grass.

Certainly, in the gerais golden grass fire 'converges' (Santos 2015: 89) with cattle fire. Precisely through this confluence - that is, by "coming together without merging" - each living being possesses its own rhythm of queimada. As the elder Deni told me in a conversation around the bonfire, while the cattle feed on the shoots of a burn made the same year, ${ }^{14}$ golden grass 'grows strongly' only in those vargens burned the year before. In other words, the cattle will eat its shoots during the same year that the area was burnt, while golden grass has a more extended life cycle. For the latter, the sprouting time or esverdescimento (greening) lasts the entire rainy season, usually spanning from the end of October to April. Between May and June sprout the little clusters or shoots from which the plant's flowers, fruits and seeds will emerge. July and August, in turn, are understood as the months of ripening or douração (time of gilding), which ends between the end of September and the beginning of October with the harvest or tempo da ranca (time of pulling up).

It is not common practice to burn the same vargem over successive years. If this happens, the golden grass fraqueia (weakens) and even the sprouts of wild grass for cattle will not sprout abundantly - in other words, it will not be a good burned place or suquiadeira. On the other hand, leaving a vargem for more than three years without burning is not a diligent attitude in relation to living beings either. As well as "only piling up bad stuff," the accumulation of cru (raw) grass generates a very intense fire that, as it passes, leaves the soil thinner, reducing the number of new shoots of both golden grass (capim-dourado) and wild grass for the cattle. This is why both fires, whether made for cattle or for golden grass, should follow a frequency of biennial burning. To harmonize these singularities and confluences, the geralista should deploy at least three temporalities of burns in the veredas landscape:

- burned place (queimadas) made between the months of May and July of the current year in order to feed cattle during the summer (verão: July-October) and provide golden grass the following year;

\footnotetext{
14 In the vargens of the veredas, shoots begin to sprout about 8 days after passage of the fire. However, cattle breeders tend to wait around 15 days for the vargem to reform and only then take their cattle - that is when the animal has not gone by itself already after sensing the odour of burning grass. In cerrado areas (chapada and campina), the time for sprouting and reforming may take up to 30 days.
} 
- low burns (queimadas baixas) - that is, burns made the previous year - protected from the unpredictable fires (fogos variados) that may arise, in order to provide a harvest of golden grass during the current year;

- areas of dry meadow (vargem cru), unburnt and protected from any fire during the current year, to be burnt for cattle the following year and also provide golden grass in the subsequent year.

Since cattle only eat shoots in the meadows (vargens), cattle and golden grass can live together in the same queimada. Moreover, at the level of 'planning' or 'management' too, if we wish to use these terms, a favourable confluence exists: a vargem where golden grass was gathered in the current year (between the end of September and the beginning of the rains) can potentially be burnt to generate grass the following year. Even then, the cattle can still feed on the shoots from the burn during this same year. In any event, although the fire made for golden grass also serves for cattle, Deni typically says that it is the di cumê (feed) for the cattle that guides his planning:

My plan is geared more for the cattle. We plan for the cattle and the cattle fire in the summer [verão] is the same as the fire for the golden grass. So the management is more for the cattle. Because burning for the cattle burns for the grass too. Because if I burn for the grass, there will be none for the cattle later. [...] That's why it's better to burn with the cattle in mind. We think about the cattle a lot. (Deni)

Given the singular but connected rhythms of burns for cattle and golden grass, it might be said, somewhat precipitately, that quilombola management revolves entirely around a temporal rationalization of the uses of the veredas, thus conceived as a 'resource.' However, although there are temporalities valued as 'normal' for the passage of fire vis-à-vis living beings (especially cattle, golden grass and game animals), life in the gerais is shaped by events that, for the geralista, render impossible any attempt to stabilize time through the rigidity of calendars. This is precisely one of the major forces of interaction between the cattle and golden grass fires. A fire that 'opened up' (spread) too much one year, potentially leave the cattle without shoots for the next, will nevertheless provide a large harvest of golden grass.

During the summer of 2016, the relation of kinship (compadrio) between Deni and Veinho, mediated through the sharing of burned places (queimadas), was also a necessary condition for a fire that "spread up too much" not to be experienced with discontent. After all, the temporal diversity of the burnt areas within the quilombola territory, combined with the reciprocity intrinsic to the compadrio, compose a healthy life (vida sadia), without old cru and cultivated in friendship, making it possible for the geralista to recreate through erratic events like the fires that spreads up. In this sense, a healthy life in the gerais entails diverse risks, since it involves being open to innumerable contingencies and, through them, to finding creative solutions.

\section{Fire out of time and other pathologies}

Canguilhem defines pathology as an anomaly of necessarily negative vital value, that is, "when its effects are assessed in relation to a defined milieu in which certain tasks have become unavoidable for the living being" (Canguilhem 2008: 129). However much they provoke a restructuring of plans, events like the one lived by Deni and Veinho in the summer of 2016 are recurrent in the gerais. In fact, although this fire had been an anomaly - in the sense of its unusualness, diverging from the forms desired for a 'beautiful burn' - it should not be characterized as pathological. No anomalous fire or fire taken as uncontrolled can be seen as normal or pathological in itself, but only when conceived within the ecological relations that it will establish with associated forms of life. A fogo que abre (fire that spreads up), also called a fogo gerais (general fire), may even burn in excessively, sem precisão (without precision), provoking an aesthetic or quantitative discontinuity visà-vis desired fire. Nonetheless, such a discontinuity is not always qualitative to the point of being experienced 
as pathological. Put otherwise, to be recognized as necessarily reducing the capacities for action, not only does the fire's extent need to be considered, but above all the forms of life that may atrophy as a result of the burning. In contraposition to the anomalous form of fogos gerais (general fires or fire that spreads), we can take as an example the negative valorization attributed by the geralistas to what they call fogo fora do tempo (fire out of time):

There are two fogo fora do tempo that are bad for us: fire from November to March is really bad for cattle breeders.

And that fire from August to September, until the first fortnight of October. That's the worst fire for us here.

Because it's the driest, hottest season, and all the animals are producing. (Deni)

What is interesting to highlight in Deni's comment on the two fogo fora do tempo is the way in which their negative valorization is linked to living beings. The value of fire from November to March is informed by the cattle and the loss that it may cause the breeder, while avoiding the second fire, from August to September, is related to the bichos (animals linked to the universe of hunting). Both are valued, therefore, through temporalities associated with the life cycles of living beings, in particular because the queimadas (burned places) compose not only the niches of the cattle and golden grass, but also of the rhea (Rhea americana) and deer. ${ }^{15}$

Approaching the problem in the terms proposed by Ana Tsing (2015: 181), queimadas can be seen as 'familiar places' through which we can gain a privileged insight into diverse multispecies interactions. To take one example: a striking presence in the act of burning itself is the savanna hawk (Heterospizias meridionalis), called 'gavião-fumaça,' or 'smoke hawk.' Always located high above - either hovering in the air or perched at the top of a tree close to the flames - this bird of prey can perceive smoke rising from kilometres away during the daylight. Because of its singular habit of following the smoke, a common expression is "where there is the smoke hawk, there is fire." For the bird, smoke is a sign of fire and the latter, in turn, signals the chance to capture its prey. Its hunting behaviour involves gliding on the updrafts of hot air caused by convection and then swooping down in shallow dives, searching for insects trying to escape the flames and heat, when located in advance of the fire, or catching those already dying, when hunting in its wake.

The perceptual apparatus of rheas is also attuned to the flight of microfauna, especially bugs and small lizards, which is why they arrive at the queimada on the same day that the fire has passed through - making use of their zoio bom (good eye) for smoke. After around eight days (when in the vargem milieu) to fifteen (when in the chapada), the rheas will return, this time to eat the shoots, giving rise to the wild grass grazing phase. They may also encounter some deer, which "sniff the wind and follow the scent," and also approach at this moment to eat the shoots and flowers of the cerrado. Deer, however, prefer the leaves and shoots of tree species. But while rheas prefer queimadas in chapada milieu, especially since this is also where they will later build their nests, the subspecies of deer have distinct preferences: the veado do campo (savanna deer, or campeiro) is more attracted to the wild grass shoots of the chapada, while the veado do pântano (marsh deer, or sussuapara) is more commonly linked to the queimadas of the vargem. In search of rhea and deer comes the jaguar, the apex of the food chain. Due to its potential presence, it is never recommendable to spend the night in locations close to a queimada more than a month old.

As well as the fire paths inscribed in the landscape, the queimadas are milieus from which life forms emerge and develop. If milieus are filled with meaning even for a tick, as Von Uexkull (2010) demonstrated, what to say of the rheas, savanna and forest deer, sussuaparas and smoke hawks - to mention just some examples of this geralista fauna? All these living beings have their own perceptions of the queimadas anchored in actions performed in a manner closely paced with the movements of animals and plants that follow the passage of fire. Based on the singularities of this geralista fauna, it would be no exaggeration to affirm that the queimadas

15 The most common varieties are the 'savanna deer' (Ozotoceros bezoarticus), 'forest deer' (Mazama americana) and 'marsh deer' or sussuapara (Blastocerus dichotomus). 
are traversed by the 'own worlds' (umwelt) of these living beings (Uexkull 2010). Worlds that overlap with equally singular temporalities via temporal paths that grow and age. While the queimadas novas (new burnt areas) are inhabited by rheas, deer and all kinds of foraging animals, the queimada velha (old burnt area) is the place of cru velho (old dry grass), poisonous snakes and "everything that is bad!" By rhythm, I understand "a communication of milieus, coordination between heterogeneous space-times" (Deleuze and Guattari 1987: 313), we could say that each of these milieus is vibratory and expresses a rhythmicity since it articulates blocks of spacetime between the coming and going of fauna. In the ethological intuition of Deleuze and Guattari (1987: 314), the territory of these animals of the queimada is "the product of a territorialization of milieus and rhythms."

The geralistas base their evaluation of what a 'good fire' is primarily on what the queimadas provide to living beings. However, the potential reduction in the capacities of vital action caused by fires also grounds their negative evaluations. The fogo fora do tempo (fire out of time) of summer mentioned by Deni, spanning between the months of August and September, takes the bichos (game animals) as a normative reference point. This period of the year, the height of the quentura (heat) and the sequidão (drought), coincides with what is called the "period of rhea production." For this reason, not only is the fogo fora do tempo of August and September avoided, it is also necessary to preserve the queimadas baixas (low burns, newly regenerated) $\cdot^{16}$ The best period for lighting this fire, which will later constitute the queimadas baixas, are the months of April and May when the fire tends not to spread too rapidly. Without the queimadas baixas, the life cycle of the rheas is put at risk. After all, the fogo fora do tempo in August and September may not only destroy the nests but also kill the new-born fledglings. This is why only the fogo de precisão (precision fire) is tolerated in August and September - that is, used only in extreme cases in order for cattle not to go hungry - as long as it is done in a vargem (meadow) already with a cleared firebreak.

When it comes to the fogo fora do tempo of the winter, the cattle breeders are unanimous concerning its harmful effects on their livestock. These involve the queimadas made in hot spells during the rainy season, especially between the months of December and April, in the vargens. The explanation given for this practice is what the geralistas call mal-de-toque ('toque' malady), a bovine disease characteristic of the sandy soil of the gerais. Although few zootechnical studies mention mal-de-toque, this disease takes up much speculative space in the geralista imagination, particularly in relation to the concerns of cattle breeders. This is why the fogo fora do tempo that provokes the disease has to be avoided:

Vargens cannot be burnt in the winter. It's because of the wet vargens. Because these vargens will sprout in the rains. They sprout in the water and the cattle will eat in those vargens filled with water. It's when the soil sticks to the grass. Then we have to bring them to the plantation, because the plantations will already be good; there's already pasture. It's the time to take them to the plantations. Because if we leave them in the gerais all year round, summer and winter, we end up with all the cattle tocado [affected by mal-de-toque]. (Deni)

The sickness unfolds as follows: during the winter, amid the rains, the fine sand of gerais tends to stick to the bucha (lower stem) of the wild grass. When they eat it, the cattle also ingest a lot of this sand, which accumulates in an internal section of the animal's digestive tract that geralista anatomy denominates livro 'the livro of the cattle.' The first symptoms become perceptible when the animal begins to expel catarrh or pus through its venta (snout), its hair becomes split and bristly, it walks with its head low, becomes blind or variado (insane) or even develops a hollow horn to the point of air escaping when perforated. Some check the diagnosis by giving the animal Coca-Cola to drink, using it as a purgative, and then assessing the amount of sand in the faeces.

16 These are areas burnt the previous year, especially in the chapada and campina environments, where the rheas are known to build their nests, taking advantage of the gaps in the grass that function as aceiros, firebreaks, protecting their nests from embalado (rapid) fires. 
After verifying the mal-de-toque, the geralista will use his roça de pasto (pasture) to destocar (action to counter the malady) the affected cattle. In it there are exotic varieties of grass, which are take as stronger and less vulnerable to the sand that sticks to the base of wild grass. The fact is that if there is no pasture planted in the vedadas (protected) plantations to cure the cattle, the animals may even die. Since the majority of cattle breeders lack large areas of planted pasture, the therapeutic action involves a rotation between the roça de pasto (pasture) and a queimada in the chapada milieu made close to the breeder's house. A roça de pasto of 2 hectares, for examples, enables around 10 cattle to be cured over the course of a month. After this period, the herd is led back to feed on the shoots in the chapada until the planted pasture sprouts again:

Let's suppose I bring the cattle in November. I spend November there and a part of December. Even if it is training, the wild grass is sprouting. Then the cattle is destocado [cured] and returns there, spending ten, fifteen, twenty or thirty days until the plantation sprouts again. When the plantation germinates, I bring the cattle back to it. Here I make them fast. I give them salt with minerals... Even there in gerais, during this period I round them up in the enclosure, they spend a day without eating. I give them salt with minerals and they lick it. After a month, thirty days spent there in gerais, I bring them back and place them here again. I spend ten, fifteen days with them and return again. And they're cured. (Deni)

Here a point should be emphasized: this metastable relation between toque and destoque, a sick life and a healthy life, which accompanies the geralista and his herd throughout the rainy season, constitutes something specific to the regime of breeding cattle na solta (free range). In effect, rather than opposing normal life, in the gerais the mal-de-toque should be contrasted with a vida sadia (healthy life). This is because the tocada life does not lack norms but is situated within other norms. Although the toque is perceived by the breeder as an affliction or a symptom of something we might call 'disease' - in the sense of a fixation or "fidelity of the organism to a single norm" (Safatle 2015:436) - it is still also the seed from which new behaviours develop. The imminence of the toque is one of the vectors of force that drive the transhumant rotation of the cowherds and their cattle between the roças de pasto (planted pastures) and the queimadas de porta (burned areas near the home). As a disease to be avoided, it produces new norms of adaptation between the cattle and their milieus in a reconciliation lived through the restriction in the bovine capacity for action. Although the affected cattle remain under the care of the breeder, expressing a qualitatively more vulnerable form of life since intolerant of deviations in conduct, the toque is not seen as something to be overcome. Rather, it is recognized as something intrinsic to breeding na solta. In this sense, it composes a form of life (Pitrou 2017), generating concrete effects on the normativities of fire and on the modes of dwelling in the gerais.

\section{Final considerations}

To singularize the disparities between desired and undesired fires in the gerais, the first challenge of my research was to avoid adhering to legal and administrative normativities, enabling instead the emergence of existential modes of fire in the ethnography that otherwise escape official grammars based on an abstract notion of 'control.' As a consequence, running counter to the instrumental narratives that conceive fire (and perhaps technique in general) as a utilitarian tool of production, acquisition or even environmental management, the technicity of fire in the gerais could only be analysed within living dynamics in direct relationship with the 'own worlds' (umwelt) that traverse the queimadas and with the rhythms that ensure that burns are not made out of time. Such being the case, as well as action on matter, here techniques of fire acquire the status of means of perception through which multispecies interactions are comprehended. In this sense, more than a 'tool,' the diverse types of fire, particularly the queimadas, are means to perceive bovine transhumance, the life cycles of 
animals and the growth of golden grass. We could go even further, arguing that quilombola geralista thought offers a theory of life (Pitrou 2014 and 2017) in which the harmonic and rhythmed existence between fire and forms of life ensures the possibility of a vida sadia (healthy life).

In conclusion, I wish to remark on some points for future reflection. I began this text by showing how the need to redefine and reach conceptual agreement on the wildfires or 'bad fire' was a necessary condition for reconciling conservationism in Jalapão. This way of envisaging perceptual disparities as 'misunderstandings' centres on the belief that disagreements are situated in the sphere of verbal communication, resolvable through use of a general grammar capable of comparing points of view. Nonetheless, if we take seriously geralista thought, the normalization of the dualism 'good fire' versus 'bad fire' based on quantitative criteria of time (early/late) and space (area size) is only sustainable at a pragmatic level. After all, the generic notion of wildfire, which would be better compared to the notion of abnormality, understood as a quantitative variation of the normal, reveals a perception that has very little to do with the pathological qualities of fogo fora do tempo and the anomalies of fogos gerais. Likewise, the translation of the universe of multispecies interactions of the queimadas in terms of 'good fire' or 'controlled fire' ends up decontextualizing and isolating them from their relations with associated forms of life.

Beyond the translation and sharing of concepts, the transition from fire combat to fire management involves the circulation of other affections that gravitate around fire. Prior to the advent of Integrated Fire Management (IFM), the phobia of environmental management in relation to fire encapsulated the socioenvironmental conflicts over the legal protocol of 'being able to burn' and 'not being able to burn,' based on the allocation (permissions) and nullification (fines) of rights. After the IFM, the quilombolas were permitted and even encouraged to burn, so long as their fires met what was defined and agreed as a 'good fire.' In effect, this shift from a disciplinary power over fire to what we could call a new 'pyropolitics' begins to centre on the modulation of the relationships between organisms and milieus - that is, precisely on what has been understood over the course of this text as technique. However, it needs to be stressed that the effects of this encounter are not unidirectional: while the quilombolas begin to share the negative affects surrounding wildfires, for the managers too a queimada becomes perceived in a much more dynamic way than a mere lifeless space.

Submission: September 22, 2018

Accepted: September 17, 2019

Translated by: David Rodgers 


\section{Bibliography}

ANDRIOLLI, Carmem Silvia. 2011. Sob as vestes de Sertão Veredas, o Gerais: mexer com criação no Sertão do IBAMA. Tese de doutorado, Programa de Pós-graduação em Ciências Sociais da Universidade Estadual de Campinas - Campinas.

APOLINÁRIO, Juciene Ricarte. 2005. Os Akroá e outros povos indígenas nas fronteiras do Sertão: as práticas das políticas indígenas e indigenistas no norte da capitania de Goiás - Século XVIII. Tese de doutorado. Programa de Pós-Graduação em História da Universidade Federal de Pernambuco - Recife.

ARRUTI, José Maurício. 2006. Mocambo: Antropologia e história do processo de formação quilombola. 1. ed. Bauru: Edusc.

BACHELARD, Gaston. 1964 [1938]. The Psychoanalysis of Fire. Translated by Alan C. M. Ross. New York: Beacon Press.

BARBE, Noel; BERT, Jean-François. 2009. Penser le concret. André Leroi-Gourhan, André-Georges Haudricourt, Charles Parain. Paris : Créaphis.

BARRADAS, Ana Carolina Sena. 2017. A Gestão do fogo na Estação Ecológica Serra Geral do Tocantins, Brasil. Dissertação de Mestrado. Rio de Janeiro: Instituto de Pesquisas Jardim Botânico do Rio de Janeiro.

BARRADAS, Ana Carolina Sena; BORGES, Marco Assis; COSTA, Máximo Pereira da. 2014. Plano de Proteção da ESEC Serra Geral do Tocantins 2014. ICMBio.

BIDET, Alexandra. 2007. "Le corps, le rythme et l'esthétique sociale chez André Leroi-Gourhan," Techniques \& Culture, 48-49: 15-38.

BILBAO, B.; LEAL, A.; MENDEZ, C. 2010. "Indigenous use of fire and forest loss in Canaima National Park, Venezuela. Assessment of and tools for alternative strategies of fire management in Pemón indigenous landscape ecology." Human Ecology, 38: 663-673.

BOWMAN, D. M.; PERRY, G. L.; HIGGINS, S. I.; JOHNSON, C. N.; FUHLENDORF, S. D.; MURPHY, B. P. 2016. "Pyrodiversity is the coupling of biodiversity and fire regimes in food webs.", Phil. Trans. R. Soc. B, 371: http://doi.org/10.1098/rstb.2015.0169

BRUM, Eliane. 1994. Coluna Prestes: o Avesso da Lenda. Porto Alegre: Artes e Ofícios.

BYRAM, G. M. 1959. "Combustion of forest fuels.” In: K. P. Davis, Forest Fire: control and use. New York: Mc Graw Hill. pp. 61-89.

CANGUILHEM, Georges. 1991. The Normal and the Pathological (transl. Carolyn R. Fawcett). New York: Zone Books.

. 2002. O normal e o patológico (trad. Maria Thereza Redig de Carvalho Barrocas). Rio de Janeiro: Forense Universitária. . 2008. Knowledge of Life. New York: Fordham University Press.

DELEUZE, Gilles; GUATTARI, Félix. 1987. A Thousand Plateaus. Capitalism and Schizophrenia. Minneapolis: University of Minnesota Press.

DUMEZ Richard. 2010. Le feu, savoirs et pratiques en Cévennes. Paris: Editions Quæ.

ELOY, L.; SCHMIDT, I. B.; LÚCIO, S.L.B.; CARDOSO, M.; SANTOS, T. 2018. "Seasonal fire management by traditional cattle ranchers prevents the spread of wildfire in the Brazilian Cerrado". AMBIO, 1: 1-10.

FALEIRO, Rodrigo. P. 2002. "Relatório Técnico-científico de Antropologia: Jalapão sob perspectiva social um breve recorte histórico social da comunidade Mumbuca e da sede do Município de Mateiros -TO”. In: M. B. Arruda; M. Von Behr (eds.), Jalapão: Expedição técnico-científica. Brasília: IBAMA. pp. 51-82.

.; SANTANA, M. T.; BERNI, C. R. 2016. "As contribuições do Manejo Integrado do Fogo para o controle dos incêndios florestais nas Terras Indígenas do Brasil”. Revista Biodiversidade Brasileira, 6(2): 88-105.

FERRET, Carole. 2014. "Towards an anthropology of action: From pastoral techniques to modes of action." Journal of Material Culture, 19(3): 279- 302. 
FOUCAULT, Michel. 2010. “Aula de 17 de março de 1976.” In: Em defesa da sociedade. São Paulo: Martins Fontes. pp. 201-222.

FOWLER, Cynthia. 2013. Ignition stories: indigenous fire ecology in the Indo-Australian monsoon zone. Durham: Carolina Academic Press.

GARDA, Ângela; BERLINCK, Christian. 2016. Histórico do Fogo no Brasil com Enfoque na Gestão de Unidades de Conservação Federais. Brasília: ICMBio.

GEIGER, Pedro Pinchas. 2014 [1942]. "Excursão ao Jalapão”. Revista Terra Brasilis, (Nova Série) [Online], 3: 1-44.

GIBSON, James. 1979. An ecological approach to visual perception. Boston: Houghton Mifflin.

GUCHET, Xavier. 2010. Pour un humanisme technologique. Culture, technique et société dans la philosophie de Gilbert Simondon. Paris: PUF.

HAUDRICOURT, André-Georges. 1962. "Domestication des animaux, cultures des plantes et traitement d'autrui." L'Homme, 2(1): 40-50.

INGOLD, Tim. 2011. Being alive: essays on movement, knowledge and description. London: Routledge. 2017. "Anthropology Contra Ethnography." HAU, 7(1): 21-26.

JACINTO, Andrea Borghi Moreira. 1998. Afluentes da memória: itinerários, taperas e histórias no Parque Nacional Grande Sertão Veredas. Dissertação de mestrado, Pós-Graduação em Antropologia, Universidade de Campinas - Campinas.

LEROI-GOURHAN, André. 1984 [1943]. Evolução e técnicas I - O homem e a matéria. Lisbon: Edições 70. . 1993 [1965]. Gesture and Speech, trans. A. Bostock Berger, ed. R. White. Cambridge, MA: MIT Press.

LINDOSO, Lilian de Carvalho. 2014. Recursos de uso comum nos Gerais do Jalapão: uma análise institucionalista do Termo de Compromisso com populações tradicionais no interior de Unidades de Conservação. Dissertação de mestrado, Programa de Mestrado em Desenvolvimento Regional, Universidade Federal do Tocantins Palmas.

MARTIN R. E.; SAPSIS, D. B. 1992. "Fires as agents of biodiversity: pyrodiversity promotes biodiversity." In: Proceedings of the conference on biodiversity of northwest California ecosystems. Cooperative Extension. Berkeley: University of California. pp. 150-157.

MAUSS, Marcel. 2007. Manual of Ethnography. New York/Oxford: Durkheim Press/Berghahn Books. . 2003. “Técnicas do corpo." In: Sociologia e Antropologia. São Paulo: Cosac\&Naify. pp. 399-422.

MIRANDA, Agenor Augusto de. 1936. O Rio São Francisco (A Zona do Jalapão). São Paulo: Companhia Editora Nacional.

MISTRY, J.; BILBAO, B. A.; BERARDI, A. 2016. "Community owned solutions for fire management in tropical ecosystems: case studies from Indigenous communities of South America”. Philos Trans R Soc Lond B Biol Sci.; 371(1696): 20150174. doi:10.1098/rstb.2015.0174

MYERS, Ronald 2006. Living with Fire - Sustaining Ecosystems \& Livelihoods Through Integrated Fire Management. The Nature Conservancy Global Fire Initiative. USA: Tallahassee.

NOGUEIRA, Monica. 2009. Gerais a dentro e a fora: identidade e territorialidade entre geraizeiros no Norte de Minas Gerais. Tese de doutorado, Programa de Pós-graduação em Antropologia Social da Universidade de Brasília - Brasília.

PALSSON, Gisli. 2013. “Ensembles of biosocial relations.” In: Tim Ingold and Gisli Palsson (eds.), Biosocial Becomings. Integrating social and biological anthropology. Cambridge: Cambridge University Press. pp. 22-41.

PARR, C. L.; ANDERSEN, A. N. 2006. "Patch mosaic burning for biodiversity conservation: a critique of the pyrodiversity paradigm." Conservation Biology, 20: 1610-1619.

PATERNOSTRO, Júlio. 1934. Viagem ao Tocantins. São Paulo: Companhia Editora Nacional. 
PETRYNA, Adriana. 2018. "Wildfires at the Edges of Science: Horizoning Work Amid Runaway Change".

Cultural Anthropology, 33 (4): 570-95.

PEREIRA, Gilvandro Simas. 2014 [1942]. “Expedição ao Jalapão.” Terra Brasilis: revista Brasileira da Geografia, 3: 1-44.

PITROU, Perig. 2014. "La vie, un objet pour l'anthropologie? Options méthodologiques et problèmes épistémologiques." L'Homme, 212: 159-189.

. 2016. "Ação ritual, mito, figuração: imbricação de processos vitais e técnicos na mesoamérica e nas terras baixas da américa do sul (Introdução).” Revista de Antropologia, 1: 6-32.

. 2017. "Life form and form of life within an agentive configuration: a birth ritual among the Mixe of

Oaxaca, Mexico". Current Anthropology, 58(3): 360380.

PYNE, Stephan J. 1984. Introduction to Wildland fire: Fire Management in the United States. New York: John

Wiley and Sons.

. 2012. Fire: nature and culture. London: Reaktion Books.

RABINOW, Paul. 1999. "Vida, normas e erros: o trabalho de Georges Canguilhem”. In: João G. Biehl (ed.),

Antropologia da razão: ensaios de Paul Rabinow. Rio de Janeiro: Relume Dumará. pp. 123-135.

RIBET, Nadine. 2009. Les parcours du feu. Techniques de brûlage à feu courant et socialisation de la nature dans les Monts d'Auvergne et les Pyrénées centrales. Thèse de Doutorat, EHESS - Paris. . 2018. Feu: ami ou ennemi?. Malakoff : Ed. Dunod.

RIBEIRO, Eduardo Magalhães. 2010. “As Histórias dos Gerais”. In: Eduardo Magalhães Ribeiro (ed.), Histórias dos Gerais. Belo Horizonte: Ed. UFMG. pp. 23-39.

ROSA, João Guimarães. 2001. Grande Sertão: Veredas. Rio de Janeiro: Nova Fronteira.

RUSSELL-SMITH, J.; COOK, G. D.; COOKE, P. M.; EDWARDS, A. C.; LENDRUM, M.; MEYER, C. P.; WHITEHEAD, P. J. 2013. "Managing fire regimes in north Australian savannas: applying Aboriginal approaches to contemporary global problems." Frontiers in Ecology and the Environment, 11: 55-63.

SAFATLE, Vladmir. 2015. "Uma certa latitude: Georges Canguilhem, biopolítica e vida como errância." In: $O$ circuito dos afetos: corpos políticos, desamparo e o fim do indivíduo. São Paulo: Cosac Naify. pp. 409-454.

SANTOS, R M dos. 2013. Os Gê dos gerais: elementos de cartografia para etno-história do Planalto Central. Contribuição à antropogeografia do Cerrado. Dissertação de mestrado. Centro de Desenvolvimento Sustentável, Universidade de Brasília.

SANTOS, Antônio Bispo dos. 2015. Colonização e quilombos: modos e significados. Brasília: Instituto Nacional de Ciência e Tecnologia de Inclusão no Ensino Superior e na Pesquisa; Universidade de Brasilia; Ministério da Ciência, Tecnologia e Inovação.

SIGAUT, François. 1975. L'agriculture et le feu. Paris: Mouton

SIMONDON, Gilbert. 2005a [1965-1976]. L’invention dans les techniques: cours et conférences. Paris: Seuil. . 2005b [1958]. L’individuation à lumière des notions de forme et d’information. Grenoble: Éditions Jérôme Millon.

SOBRINHO, José de S. 2012. O Camponês Geraizeiro no Oeste da Bahia: as terras de uso comum e a propriedade capitalista da terra. Tese de Doutorado, Programa de Pós-Graduação em Geografia Humana da Universidade de São Paulo - São Paulo.

TROLLOPE, W. S. W. 2011. "Personal perspectives on commercial versus communal African fire paradigms when using fire to manage rangelands for domestic livestock and wildlife in Southern and East African ecosystems." Fire Ecology, 7: 57-73.

TSING, Anna. 2015. "Margens indomáveis: cogumelos como espécies companheiras." Ilha - Revista de Antropologia, 17(1): 177-201. 
UEXKULL, Jacob von. 2010 (1934). A foray into the worlds of animals and humans (with a theory of meaning). Minneapolis, London: University of Minnesota Press.

VON BEHR, Miguel. 2004. Jalapão: sertão das águas. São José dos Campos, SP: Somos Editora.

\section{Guilherme Moura Fagundes}

Postdoctoral research fellow (PNPD/CAPES), University of Brasília (UnB), Brasília/DF, Brazil. https://orcid.org/0000-0003-2510-0465

Author's e-mail: guilhermefagundesantro@gmail.com 